\title{
Combined Treatment of Brain AVMs by Onyx Embolization and Gamma Knife Radiosurgery Decreased Hemorrhage Risk Despite Low Obliteration Rate
}

\section{Onyx Embolizasyonu ve Gamma Bıçă̆ı Radyocerrabisi ile Beyin AVM'lerinin Kombine Tedavisi Obliterasyon Oranının Düşük Olmasına Karşın Kanama Riskinde Azalma}

\author{
Xiaochuan HUO, Youxiang LI, Zhongxue WU, Yuhua JIANG, Hongchao YANG, Yang ZHAO \\ Capital Medical University, Beijing Neurosurgical Institute and Beijing Tiantan Hospital, Department of Interventional Neuroradiology, \\ Beijing, China
}

Corresponding Author: Youxıang LI / E-mail: doctorliyouxiang@163.com

\begin{abstract}
AIM: The effectiveness and risk of cerebral arteriovenous malformations (AVMs) treatment with Onyx embolization combined with Gamma Knife surgery (GKS) were rarely reported. In the present study, we analyzed the radiographic and clinical outcomes of combined Onyx embolization and GKS for cerebral AVMs.

MATERIAL and METHODS: A total of 86 patients' clinical outcomes were fully collected. Modalities and complications of the procedure were analyzed as well as the clinical and anatomic outcomes. Risk factors associated with hemorrhage were determined by multivariate analysis.

RESULTS: The mean duration of radiological and clinical follow-up was 42 months (12.3-82.5 months) and 57.6 months (12.3-108.9 months), respectively. The total annual hemorrhage rate was $1.66 \%$ with $2.26 \%$ for ruptured AVMs and $1.08 \%$ for unruptured AVMs. The annual mortality rate was $0.4 \%$. The total obliteration rate was $28.2 \%$ at follow-up. Clinical deterioration occurred in 4 patients (4.7\%). Volume larger than $22 \mathrm{ml}$, diameter prior GKS larger than $3.5 \mathrm{~cm}$ and margin dose less than $16 \mathrm{~Gy}$ significantly increased the hemorrhage risk.

CONCLUSION: The post-treatment hemorrhage could be predictable based on AVM's characteristics and treatment approaches. The annual hemorrhage rate was low for both ruptured and unruptured AVMs after combined treatment; however, the total obliteration rate was low. Long-term follow-up and larger population are needed for evaluating the clinical effect for this combined treatment.
\end{abstract}

KEYWORDS: Cerebral arteriovenous malformations, Onyx, Embolization, Gamma knife surgery

öz

AMAÇ: Onyx embolizasyonu ile kombine Gamma Bıçağı cerrahisi (GBC) ile serebral arteriyovenöz malformasyonların (AVM'ler) tedavisinin etkinliği ve riski nadiren bildirilmiştir. Mevcut çalışmada serebral AVM'ler için kombine Onyx embolizasyonu ve GBC'nin radyografik ve klinik sonuçlarını analiz ettik.

YÖNTEM ve GEREÇLER: Toplam 86 hastanın klinik sonuçları tam olarak toplandı. İşlemin modaliteleri ve komplikasyonları ve ayrıca klinik ve anatomik sonuçlar analiz edildi. Kanama ile ilişkili risk faktörleri multivaryant analiz ile belirlendi.

BULGULAR: Radyolojik ve klinik takibin ortalama süresi sırasıyla 42 ay (12,3-82,5 ay) ve 57,6 ay (12,3-108,9 ay) bulundu. Toplam yıllık kanama oranı rüptüre $\mathrm{AVM}$ 'ler için $\% 2,26$ ile rüptüre olmamış AVM'ler için \%1,08 ve toplam olarak \%1,66 bulundu. Yıllık mortalite oranı \%0,4'tü. Toplam obliterasyon oranı takipte \%28,2 bulundu. Klinik bozulma 4 hastada (\%4,7) görüldü. Hacmi 22 ml üstünde olması, GKS öncesinde çapın 3,5 cm'den fazla olması ve üst sınır dozunu 16 Gy'in altında olması kanama riskini önemli ölçüde artırdı.

SONUÇ: Tedavi sonrası kanama AVM'nin özellikleri ve tedavi yaklaşımları temelinde öngörülebiliyordu. Yıllık kanama oranı kombine tedavi sonrasında rüptüre olan ve olmayan AVM'ler için düşüktü; ancak toplam obliterasyon oranı da düşüktü. Bu kombine tedavinin klinik etkisini değerlendirmek için uzun dönemli takip ve daha büyük bir popülasyon gereklidir.

ANAHTAR SÖZCÜKLER: Serebral arteriyovenöz malformasyonlar, Onyx, Embolizasyon, Gamma bıçağı cerrahisi 


\section{INTRODUCTION}

Cerebral arteriovenous malformations (AVMs) are rare congenital vascular malformations that present equally in both sexes and are typically diagnosed by the $3^{\text {rd }}$ decade of life. The incidence of AVMs as determined by various population-based studies is approximately 1 in 100.000. The annual risk of hemorrhage ranges from $1.3 \%$ to $4 \%$ per year, with an increase up to $6 \%$ to $7 \%$ in the first year after the previous hemorrhage $(7,25)$. The morbidity resulting from hemorrhage ranges from $53 \%$ to $81 \%$, whereas mortality ranges from $10 \%$ to $30 \%$, although some data suggest that the mortality rate may be lower (24).

The treatment of cerebral AVMs can be quite complicated, and indication for treatment in some clinical situations is controversial (eg. for asymptomatic AVMs). The first attempts to treat AVMs with an endovascular approach by embolizing feeding arteries was described by Luessenhop and Spence in 1960 (18). Several techniques are available for embolization, dependent on the embolization agent used and technique of microcatheterization. For large AVMs, a combined multidisciplinary approach with partial embolization to reduce the size of the nidus followed by microsurgery or radiosurgery of the remaining patent nidus has become a common practice. However, the effectiveness of this combination remains controversial. Several groups reported diverse results with obliteration rates varying between $25 \%$ and $90 \%(1,4,9,11$, 12). In most studies dedicated to the combination therapy of embolization followed by radiosurgery for the treatment of brain AVMs, particles or glue were used as the embolization agent. This combined treatment has resulted in reasonable outcomes.

We used our single center's AVM patients treated between 2004 and 2011 to check the validity of combined Onyx embolization and gamma knife surgery (GKS) for brain AVMs. To our knowledge, evaluation of Onyx embolization combined GKS treatment for AVM was rarely reported. In this study, we evaluated the obliteration rate, hemorrhage rate and the rate of procedure-related morbidity.

\section{MATERIAL and METHODS}

\section{Patient Population}

Between April 2004 and September 2011, 104 patients underwent partial Onyx embolization in the Interventional Neuroradiology Department of Tiantan hospital and this was followed by GKS at our Gamma Knife center, Beijing Neurosurgical Institute, Capital Medical University of China. Eighteen patients (17.3\%) were excluded from our study for lost follow-up or incomplete imaging follow-up. The characteristics of the patients and their AVMs prior to radiosurgery are summarized in (Table I). Eighty-six patients left for analysis were 42 female (48.8\%) and 44 male (51.2\%) with a mean age of 27.8 years. The Spetzler-Martin grade, which takes into account AVM diameter, presence of deep draining veins, and location in eloquent brain, was $I$ in 4 patients (4.7\%), II in 23 (26.7\%), III in 31 (36.0\%), IV in 20
(23.3\%), and $V$ in 8 (9.3\%). For to evaluate the outcome of GKS, we also calculated the Virginia Radiosurgery AVM Scale (VRAS) (30) which account for patient age, deep location, and AVM volume. The Virginia Radiosurgery AVM Scale was created such that patients were assigned 1 point each for having an AVM volume of $2-4 \mathrm{~cm}^{3}$, eloquent AVM location, or a history of hemorrhage, and 2 points for having an AVM volume greater than $4 \mathrm{~cm}^{3}$. (Table II) No patients undergo microsurgical resection as part of AVM management before embolization.

Sixty-four patients (74.4\%) underwent 1 embolization procedure before GKS, 10 patients (11.6\%) had 2 procedures, 6 patients (7.0\%) had 3 procedures, and $3(3.5 \%)$ had 4 procedures before radiosurgery. Twelve underwent 2 GKS (14.4\%) treatments and 1 patient had 3 treatments (1.2\%). The main presenting symptoms leading to the diagnosis of AVMs were hemorrhage in 43 patients $(50.0 \%)$, seizure in 23 patients (26.7\%), and headache in 14 patients (16.3\%).

All of the AVMs were embolized with Onyx. The volume of Onyx used for embolization range from $0.2 \mathrm{ml}$ to $10 \mathrm{ml}$, with an average of $2.2 \mathrm{ml}$. The changes in AVM sizes before embolization were based on the evaluation of embolizators by magnetic resonance imaging (MRI) or digital substraction angiography (DSA) and were calculated after embolization by computer from 3D stereotactic MR imaging in GKS center before radiosurgery. All patients with less than 2 years of imagine follow-up were excluded from the analysis of total obliteration rate, with the exception of patients who demonstrated radiological evidence of total obliteration on DSA.

\section{Treatment Strategy}

For ruptured AVM, the choice of treatment was based on anatomy and patient's condition. Surgery and embolization were the first options because they are associated with an immediate result. When embolization was chosen as the first-line treatment, the first embolization session was usually performed at least 1 month after the bleeding event. For ruptured AVMs, radiosurgery was used in selected cases as a complementary treatment in cases of incomplete treatment with surgery or embolization, or as first-line treatment if the AVM was untreatable by surgery or embolization. For unruptured AVMs, indications for treatment were based on the balance between natural history and the risks associated with the treatment. Embolization was often used as the first-line treatment followed by radiosurgery in the case of incomplete embolization.

\section{Embolization Procedure}

Embolization treatment was performed as a staged treatment, with some cases requiring several sessions. All procedures were performed with patients under general anesthesia by use of a biplane angiography system. A $6 \mathrm{~F}$ sheath was placed in the femoral artery and a 6F guiding catheter inserted into the carotid artery or vertebral artery according to AVM anatomy. A flow-directed DMSO-compatible microcatheter 
(Marathon, UltraFlow, or Apollo; ev3) was navigated into the nidus. Superselective angiography was subsequently performed to precisely analyze the angioarchitecture of the nidus, the venous drainage, and to confirm the stable position of the microcatheter distal tip. Onyx was used as the first-line embolic agent except in the case of high-flow direct fistulas or when the microcatheter was inserted in a short feeding pedicle. For Onyx embolization, the microcatheter was flushed with normal saline, and the dead space was filled with DMSO $(0.25 \mathrm{~mL})$. Onyx was then slowly injected under subtracted fluoroscopic control. In the event of reflux or passage of Onyx in the draining veins, Onyx injection was interrupted for 30 seconds to 2 minutes and then restarted. At the end of the procedure, the microcatheter was removed by gentle traction. Staged sessions of embolization were usually performed to progressively reduce the size of the circulating nidus and induce moderate nidal and perinidal changes to avoid hemorrhagic complications. Treatment by embolization

Table I: Characteristics of AVM Patients

\begin{tabular}{|c|c|}
\hline Characteristics & Value (\%) \\
\hline \multicolumn{2}{|l|}{ Sex } \\
\hline Male & $44(51.2)$ \\
\hline Female & $42(48.8)$ \\
\hline \multicolumn{2}{|l|}{ Age at presentation, years } \\
\hline Mean & 27.8 \\
\hline Median & 26.0 \\
\hline Range & $8-51$ \\
\hline \multicolumn{2}{|l|}{ Location } \\
\hline $\begin{array}{l}\text { Cerebral lobe (Frontal/ temporal/ } \\
\text { parietal/ occipital) }\end{array}$ & 67 \\
\hline Corpus callosum & 5 \\
\hline Basal ganglia & 1 \\
\hline Thalamus & 3 \\
\hline Cerebellum & 8 \\
\hline Brainstem & 2 \\
\hline Cortical & $46(53.5)$ \\
\hline Deep & $40(46.5)$ \\
\hline \multicolumn{2}{|l|}{ AVM volume (ml) } \\
\hline Mean & 23.8 \\
\hline Median & 14.1 \\
\hline Range & $0.6-115.4$ \\
\hline \multicolumn{2}{|l|}{ AVM size } \\
\hline Small $(<3 \mathrm{~cm})$ & $18(20.9)$ \\
\hline Medium $(3-6 \mathrm{~cm})$ & $56(65.1)$ \\
\hline Large $(>6 \mathrm{~cm})$ & $12(14.0)$ \\
\hline \multicolumn{2}{|l|}{ Arterial pedicle feeders } \\
\hline Single & $19(22.1)$ \\
\hline Multiple & $67(77.9)$ \\
\hline
\end{tabular}

was interrupted when it was no longer possible to access the nidus or to inject Onyx into the nidus.

\section{Radiosurgical Procedure}

Radiosurgery was performed with a Leksell Gamma Knife Unit (Elekta, Norcross, Georgia). Under monitored anesthesia for adults and general anesthetic for pediatric patients, a Leksell G-frame was affixed to the patient's head with 4 pins. The treatment target (residual nidus) was defined by 3D stereotactic MR imaging and DSA. Using a combination of DSA and MRI, the nidus was delineated and treated with radiosurgery. The embolized nidus was usually not included in the radiation targeting. On the contrary, the origin of the draining veins was usually included in the radiation targeting. The mean nidus volume was $9.95 \mathrm{~cm}^{3}$ (range $0.59-57.8 \mathrm{~cm}^{3}$ ) before GKS, the median margin dose (dose to the edge of the AVM nidus) was $16.3 \mathrm{~Gy}$ (range 13-21 Gy), the median central dose was 32.9 Gy (range $26-40 \mathrm{~Gy}$ ). A total of 13 patients

\begin{tabular}{|c|c|}
\hline Characteristics & Value (\%) \\
\hline \multicolumn{2}{|l|}{ Venous drainage } \\
\hline Superficial venous drainage & $19(22.1)$ \\
\hline $\begin{array}{l}\text { Deep and superficial venous } \\
\text { drainage }\end{array}$ & $21(22.4)$ \\
\hline Deep venous drainage & $46(53.5)$ \\
\hline \multicolumn{2}{|l|}{ No. draining veins } \\
\hline Single & 36 \\
\hline Multiple & 50 \\
\hline \multicolumn{2}{|l|}{ Presence of coexisting aneurysm } \\
\hline Intranidal & $11(12.8)$ \\
\hline Flow-related & $3(3.5)$ \\
\hline Unrelated & $2(2.3)$ \\
\hline $\begin{array}{l}\text { Presence of coexisting venous } \\
\text { aneurysm }\end{array}$ & 16 \\
\hline \multicolumn{2}{|l|}{ Spetzler-Martin Grade } \\
\hline I & $4(4.7)$ \\
\hline II & $23(26.7)$ \\
\hline III & $31(36.0)$ \\
\hline IV & $20(23.2)$ \\
\hline V & $8(9.3)$ \\
\hline \multicolumn{2}{|l|}{ Symptoms at first diagnosis } \\
\hline Hemorrhage & 38 \\
\hline Hemorrhage+seizure & 5 \\
\hline Seizures & 23 \\
\hline Migraine/headache & 14 \\
\hline $\begin{array}{l}\text { Others(Cranial nerve deficits/ } \\
\text { Hemiparesis / Hemiplegia/ } \\
\text { Dizziness/Visual deterioration) }\end{array}$ & 6 \\
\hline Asymptomatic & 1 \\
\hline
\end{tabular}


(15.1\%) with residual AVMs received repeat radiosurgery after their initial radiosurgery procedures. One patient had 2 repeat treatments and 12 had 1 repeat treatment.

\section{Radiological and Clinical Follow-Up}

Patients underwent MR imaging every 6 months. Control DSA was performed 2 years after radiosurgery but was sometimes advanced or delayed according to MR imaging results. The MRI and DSA studies were performed at a combination of facilities including those at interventional neuroradiology department of Tiantan hospital, Gamma Knife center of Beijing neurosurgical institute, and outside hospitals. All imaging studies were reviewed by an attending neurosurgeon and attending neuroradiologist of Beijing Neurosurgical Institute. If the AVM was not completely obliterated after 3 years, a multidisciplinary decision was made regarding further strategy of treatment (Table III).

Computed tomography or MRI was performed for neurological deterioration. Hemorrhage was defined by imaging studies. Patients were evaluated by DSA to confirm AVM obliteration only after MRI demonstrated absence of a residual lesion.

Table II: Virginia Radiosurgery AVM Scale (VRAS)

\begin{tabular}{|l|c|}
\hline Variable & Points \\
\hline AVM volume $(\mathbf{m l})$ & \\
$<2$ & 0 \\
$2-4$ & 1 \\
$>4$ & 2 \\
\hline AVM in eloquent location & 1 \\
\hline History of hemorrhage & 1 \\
\hline
\end{tabular}

Table III: Characteristics of GKS

\begin{tabular}{|l|c|}
\hline GKS Characteristics & Value \\
\hline Target volume (m) & \\
Mean & 9.95 \\
Median & 7.05 \\
Range & $0.59-57.8$ \\
\hline Max diameter (cm) & \\
Mean & 3.18 \\
Median & 3.15 \\
Range & $1.25-6.37$ \\
\hline Central dose (Gy) & \\
Mean & 32.86 \\
Median & 33.33 \\
Range & $26-40$ \\
\hline Margin dose (Gy) & \\
Mean & 16.29 \\
Median & 16.00 \\
Range & $13-21$ \\
\hline
\end{tabular}

Obliteration was defined by absence of abnormal arteriovenous shunting on DSA. Although DSA is the gold standard for evaluating AVM obliteration, MRI has been shown to have comparable accuracy (27).

We evaluated clinical status before and after treatment, and at the time of final telephone follow-up (2-9 years after radiosurgery) using the mRS scoring system (0: no symptoms; 1: minor symptoms; 2 : some restrictions in lifestyle; 3 : significant restrictions; 4: partially dependent; 5 : fully dependent; 6 : death).

\section{Analysis}

We performed analysis with SPSS Statistics version 17.0. A p value less than 0.05 indicated a statistically significant hazard ratio. For hemorrhage risk, the number of risk years was defined as the total time across all patients from radiosurgery to either obliteration or to last clinical follow-up in patients without hemorrhage symptom.

\section{RESULTS}

\section{Outcome of Embolization}

According to the operator's evaluation, embolization led to a decrease in the nidus volume of more than $90 \%$ in 3 patients (3.5\%), a reduction of $50 \%$ to $90 \%$ in 40 patients $(46.5 \%)$, and less than $50 \%$ in 43 patients (50\%). The shape of postembolization nidus was compact in 68 patients $(79.1 \%)$, and in 18 cases (20.9\%), the nidus was broken into several pieces. The average max-diameter before embolization was $4.12 \mathrm{~cm}$ (range $1.5-12 \mathrm{~cm}$ ) and $3.18 \mathrm{~cm}$ (range $1.25-6.37 \mathrm{~cm}$ ) after embolization. The average volume before embolization was $24.01 \mathrm{~cm}^{3}$ (range $0.75-115.38 \mathrm{~cm}^{3}$ ) and $9.95 \mathrm{~cm}^{3}$ (range 0.59 $57.8 \mathrm{~cm}^{3}$ ) after embolization. The mean Spetzler-Martin grade before embolization was 3.06 (range 1-5) and 2.71 (range 1-4) after embolization (Table IV).

Embolization related complications occurred in 13 patients (14.0\%), but most of the complications were transient and 10 patients' complication disappeared completely during the follow-up period. Only 1 patient had permanent neurologic deficit (mRS 1) and microcatheter entrapment happened in 2 patients.

Post-embolization hemorrhage occurred in 4 patients (4.7\%). Two of them were diagnosed by CT immediately after embolization and on the second day after embolization. After absorption of the hemorrhage, these 2 patients were further treated by GKS. The other 2 hemorrhages occurred 1 and 3 months after embolization separately. These 2 patients were embolized again before GKS treatment. No clinical modification was observed these 4 patients. Seven patients had transient deficit (without hemorrhage) after 1 session of embolization. Of these, 3 had hemiparesis with favorable evolution and 1 had permanent left foot muscle weakness because of thromboembolic complication. One had defect of visual field with complete recovery, 1 had temporary apnea and 1 had transient diplopia. 


\section{Obliteration Rate of Embolized AVMs After GKS}

Of all the 86 combined treatment AVMs, 46 cases were imagining followed-up for more than 2 years or demonstrated total obliteration in 2 years. The overall mean duration of imaging follow-up was 42 months (12.3-82.5 months). At 7-year follow-ups, 25 AVMs (43.0\%) were total obliterated, and all of them were diagnosed by angiography. The mean time between GKS and obliteration of the nidi was 4.68 years (range, 2.03-6.65 years). Figure 1A-D showed one 51 years-old male occurred with the symptom of grand mal epilepsy. Angiogram showed a right parietal AVM supplied by branches of right anterior cerebral artery and right middle cerebral artery. The nidus was partially embolized by $2 \mathrm{ml}$ Onyx. Six days after embolization the residual nidus were further treated by GKS. Follow-up DSA showed the nidus was completely obliterated 18 months after GKS with no clinical deterioration.

In 24 patients $(52.2 \%)$, only a partial obliteration of the residual AVM nidus was achieved after 2 years. One patient (2.2\%) did not respond at all to the GKS treatment.

Table IV: Outcome of Embolization Characteristics

\begin{tabular}{|c|c|}
\hline Embolization Characteristics & Value (\%) \\
\hline \multicolumn{2}{|l|}{ No. of prior embolizations } \\
\hline 0 & 3 \\
\hline 1 & 64 \\
\hline 2 & 10 \\
\hline 3 & 6 \\
\hline 4 & 3 \\
\hline \multicolumn{2}{|l|}{ Onyx volume (ml) } \\
\hline Mean & 2.2 \\
\hline Median & 1.8 \\
\hline Range & $0.2-10$ \\
\hline \multicolumn{2}{|c|}{ AVM decrease in size after the embolization, \% } \\
\hline $1 .<50 \%$ & $43(50)$ \\
\hline $2.50-90 \%$ & $40(46.5)$ \\
\hline 3.>90\% & $3(3.5)$ \\
\hline \multicolumn{2}{|l|}{ AVM shape after embolization } \\
\hline Compact & $68(79.1)$ \\
\hline Pieces & $18(20.9)$ \\
\hline
\end{tabular}

\section{Post embolization complications}

Transient

Hemorrhage

Hemiparesis

Defect of visual field

$1(1.2)$

Temporary apnoea

$1(1.2)$

Transient diplopia

$1(1.2)$

Permanent

Thromboembolic complication

$1(1.2)$

Microcatheter entrapment

\section{Clinical Follow-up After GKS}

All of the 86 patients were followed up for clinical status (Table V). The overall mean duration of clinical status followup was 57.6 months (12.3-108.9 months). In 29 patients, the final clinical outcome was unchanged or stable compared with the pretreatment status (33.7\%); in 42 patients (48.8\%), the clinical result was improved. A clinical deterioration after GKS was observed in 15 patients (17.4\%). Three of these

Table V: Outcome of Clinical Follow-up After GKS

\section{\begin{tabular}{l|l} 
Follow-up Characteristics & Value (\%)
\end{tabular}}

\section{Duration of clinical status follow-up (mon)}

\begin{tabular}{l|c} 
Mean & 57.6 \\
Median & 57.6 \\
Range & $12.3-108.9$ \\
Clinical status post GKS & \\
$\quad$ Stable & $29(33.7)$ \\
$\quad$ Improved & $42(48.8)$ \\
$\quad$ Deterioration & $15(17.4)$ \\
Clinical deterioration post GKS & \\
$\quad$ Hemorrhage & $9(10.6)$ \\
$\quad$ Headache & $3(3.5)$ \\
Annual hemorrhage rate for all the AVMs(\%) \\
$\quad$ Total & 1.66 \\
$\quad$ Unruptured & 1.08 \\
Ruptured & 2.26
\end{tabular}

Annual hemorrhage rate for partially obliterated AVMs (\%)

\begin{tabular}{|l|c|} 
Total & 1.77 \\
Unruptured & 1.16 \\
Ruptured & 2.42 \\
\hline Mortality & $3(3.5)$ \\
\hline Seizures symptom & \\
$\quad$ Decreased frequency & $11(39.3)$ \\
Seizure free & $14(50.0)$ \\
Increased frequency & $3(10.7)$ \\
\hline mRS scoring at diagnosis & \\
0 & $70(81.4)$ \\
1 & $10(11.6)$ \\
2 & $4(4.7)$ \\
3 & $1(1.2)$ \\
4 & $1(1.2)$ \\
\hline mRS scoring at Follow-up & \\
0 & $78(90.7)$ \\
1 & $4(4.7)$ \\
2 & $1(1.2)$ \\
6 & $3(3.5)$ \\
\hline
\end{tabular}




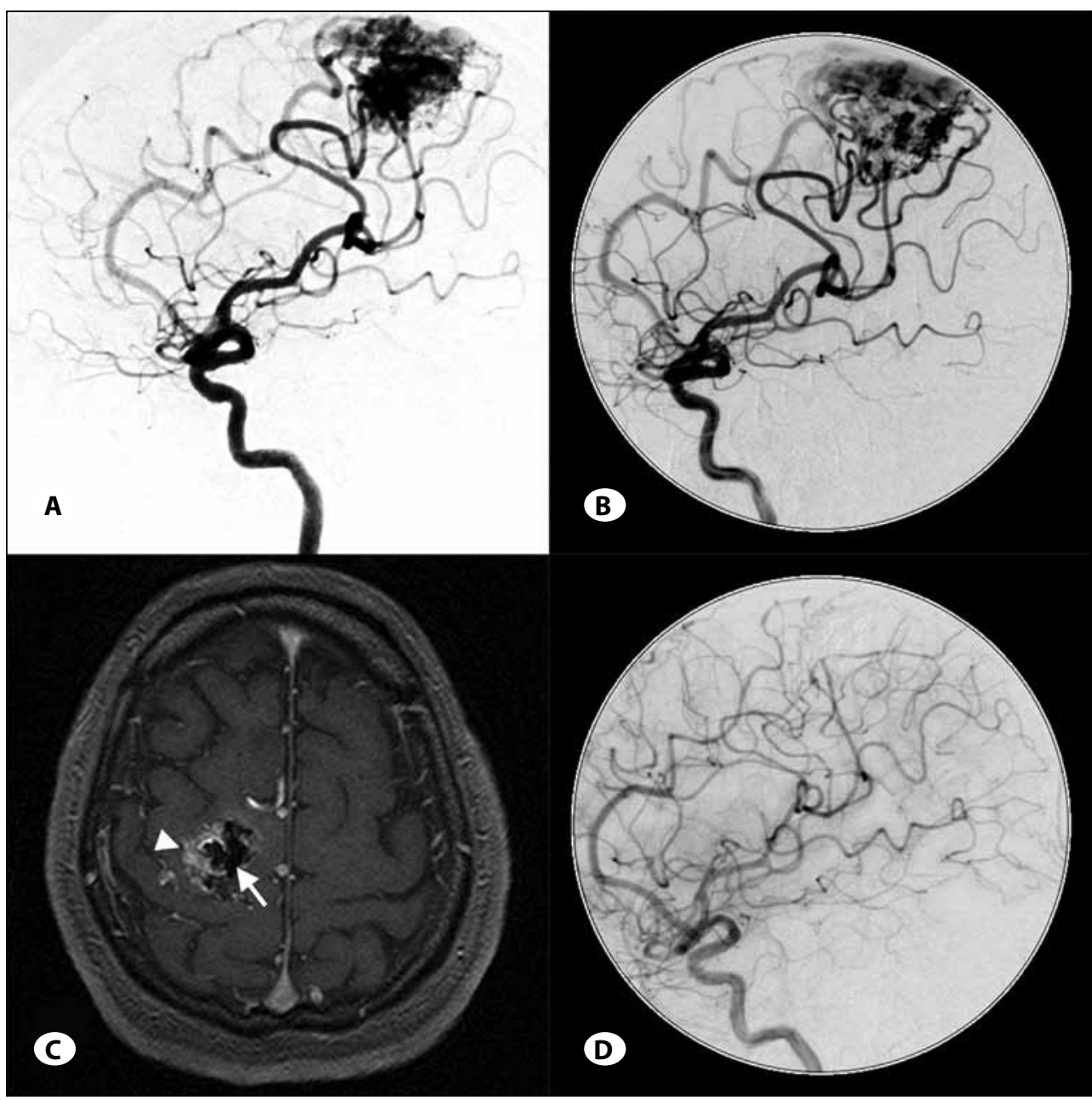

Figure 1: Obliteration of AVMs after onyx embolization followed with GKS

A) Angiogram (lateral projection) showed a right parietal AVM at diagnosis. B) The nidus was partially embolized by Onyx.

C) The treatment target was defined by 3D stereotactic MRI. Residual nidus (white, arrow head) and Onyx (black, arrow) were clearly identified by 3D-TOF MRI.

D) The nidus was obliterated completely 18 months after 1 GKS procedure. patients $(3.5 \%)$ reported the onset of new headache. Nine patients (10.6\%) experienced a hemorrhage during the follow-up period after GKS. Three patients (3.5\%) died of AVM hemorrhage and 1 of them was ruptured AVM. The annual hemorrhage rate after combined treatment was $1.66 \%$ (9 hemorrhages/407.2 risk-years) for all the AVMs, 2.26\% (6 hemorrhages/198.9 risk-years) for ruptured AVMs and $1.08 \%$ (3 hemorrhages/208.3 risk-years) for unruptured AVMs. For partially obliterated AVMs, the annual hemorrhage rate after combined treatment was $1.77 \%$ (9 hemorrhages/352.3 riskyears) for all the AVMs, 2.42\% (6 hemorrhages/171.8 risk-years) for ruptured AVMs and 1.16\% (3 hemorrhages/180.3 riskyears) for unruptured AVMs. Figure 2A-F showed a 16 years old female with the symptom of left leg lameness. Angiogram showed the right basal ganglia AVM. The nidus was partially embolized by $1.4 \mathrm{ml}$ onyx and residual nidus was treated by GKS 140 days after embolization. Follow up MRI showed decreased volume of the residual nidus and a second GKS was performed 23 months after the first GKS procedure. Four years after GKS, the patient suddenly felt headache and CT showed a hemorrhage and angiogram showed a small residual nidus with very thin feeders unable to be embolized. The patient was given expectant treatment by local hospital but finally die of malignant brain edema caused by hematoma.

Of 28 patients (32.6\%) who experienced seizures before treatment, 11 patients (39.3\%) demonstrated a decreased frequency after GKS with 7 of them taking antiepileptic and 14 patients (50\%) of them were seizure free after treatment with 1 of them taking antiepileptic. In 3 patients (10.7\%), the seizure frequency increased after GKS. Two of them relieved after antiepileptic administration and one received surgical operation to control seizure.

Clinical status was permanently worsened by embolization in 1 patient (1.2\%), with a final mRS score of 1 . Three deaths and 9 intracranial hemorrhages were observed during the followup period after GKS.

Pre-embolization mRS score was 0 in 70 patients 1 in 10 patients, and 2 in 4 patients. Preoperatively, 1 patient had a mRS score of 3 (muscle weakness related to basal ganglia bleeding), and another patient had a mRS score of 4 (aphasia related to a pretreatment stroke). Final clinical evaluation was $\mathrm{mRS}$ score of $0-1$ in 82 patients and 2 in 1 patients. Significant modification of the clinical status ( $\mathrm{mRS} 6$ ) was observed in 3 patients (3.5\%). 


\section{Factors Predicting Hemorrhage and Clinical Complications}

There were 9 post-radiosurgery hemorrhages (all patients had 1 hemorrhage) over 407.2 risk years, resulting in an annual hemorrhage risk of $1.66 \%$. Table $\mathrm{VI}$ shows the results of multivariate analysis for multiple factors and their effects on post-radiosurgery hemorrhage. The statistically significant independent positive predictors of hemorrhage were more Onyx volume, more residual nidus, deep location, more total volume, more feeding arteries, larger max diameter prior GKS, more decreased volume post embolization, less margin dose, less max dose, and higher Virginia Radio surgery AVM Scale, which provide a practical means for clinicians to predict favorable outcome after radiosurgery.

We further analyzed the value of volume prior embolization, diameter prior GKS and margin dose on post GKS hemorrhage (Figure 3A-D). Figure 3A shows the Kaplan-Meier curves of hemorrhage after GKS for AVMs. Patients with AVMs with volume prior embolization larger than $22 \mathrm{ml}$ had a significantly higher rate of hemorrhage after GKS $(p<0.05)$ (Figure $3 B$ ). Patients with AVMs diameter prior GKS larger than $3.5 \mathrm{~cm}$ had a significantly higher rate of hemorrhage after GKS $(p<0.05)$ (Figure $3 C$ ). Patients with AVMs with margin dose less than 16Gy had a significantly higher rate of hemorrhage after GKS $(p<0.01)$ (Figure 3D).

\section{DISCUSSION}

AVMs are relatively rare cerebral lesions that may cause significant neurological morbidity in young people. The treatment of cerebral AVMs requires a multidisciplinary approach that includes microsurgery, endovascular embolization, and stereotactic radiosurgery (SRS).

Embolization aiming to decrease the size of the nidus and the blood flow by occluding its critical feeders to facilitate the surgical removal by significantly shorten surgical time and to reduce blood loss or as an adjunct to surgical or radiosurgical treatment, with a concurrent reduction in morbidity and mortality $(5,13,20,23,29)$. Onyx is a precipitating agent and allows for longer injection durations and makes it possible to achieve better occlusion of the nidus in 1 injection. The use of Onyx is associated with an increasing number of AVMs cured by embolization alone. Symptoms of vascular steal phenomenon, venous hypertension, and seizures may also get some benefit from endovascular embolization $(8,16,17$, 23).

The combination of embolization and radiosurgery is often used in the treatment of brain AVMs as a routine strategy for large and complex AVMs when microsurgery is considered too risky and may render an originally untreatable AVM in a lesion potentially curable. Nevertheless, published studies of combined endovascular and radiosurgical management of AVMs have yielded controversial results. Some series have suggested that embolization before radiosurgery was associated with lower obliteration rates and worse outcomes. Andrade-Souza et al. (1) suggested that glue deposited in
Table VI: Multivariate Analysis of Factors Predicting Hemorrhage After GKS of 86 Patients

\begin{tabular}{|c|c|c|}
\hline Variables & Score & Sig. \\
\hline Sex & .182 & .670 \\
\hline Age & .532 & .466 \\
\hline Hemorrhage symptom & 1.279 & .258 \\
\hline Epilepsy symptom & 3.670 & .055 \\
\hline mRS score & .093 & .761 \\
\hline Embolization times prior GKS & .001 & .975 \\
\hline Onyx volume & 5.817 & $.016^{*}$ \\
\hline Embolization rate & 3.085 & .079 \\
\hline Shape after embolization & 3.358 & .067 \\
\hline Embolization complications & 3.108 & .078 \\
\hline Residual nidus & 26.234 & $.000^{*}$ \\
\hline Total obliteration & 1.790 & .181 \\
\hline Eloquence location & .595 & .441 \\
\hline Deep location & 5.063 & $.024^{*}$ \\
\hline Max diameter prior embolization & 3.571 & .059 \\
\hline Volume prior embolization & 7.984 & $.005^{*}$ \\
\hline Artery number & 4.499 & $.034^{*}$ \\
\hline Flow rate & 1.790 & .181 \\
\hline Draining Vein No. & .024 & .877 \\
\hline Multi-draining Vein & .028 & .868 \\
\hline Deep draining Vein & 1.641 & .200 \\
\hline Drainage location & .159 & .690 \\
\hline Coexisting Aneurysm & .261 & .610 \\
\hline Coexisting Venous aneurysm & .373 & .542 \\
\hline SM Grade & 2.180 & .140 \\
\hline Max Diameter prior GKS & 4.130 & $.042^{*}$ \\
\hline VRAS & 4.758 & $.029 *$ \\
\hline Target volume & 3.292 & .070 \\
\hline Decreased volume & 8.058 & $.005^{*}$ \\
\hline Decreased volume rate & .785 & .376 \\
\hline Central dose & 5.138 & $.023^{*}$ \\
\hline Margin dose & 6.102 & $.014^{*}$ \\
\hline
\end{tabular}

*Statistically significant $(p<0.05)$

the nidus can attenuate the dose applied by radiosurgery to the AVM by as much as $10 \%-15 \%$. However, recent studies demonstrated that prior embolization with n-BCA or Onyx does not significantly reduce the target dose to brain AVMs treated with gamma knife radiosurgery.

More recent series dealing with the treatment of brain AVMs by embolization followed by radiosurgery showed higher rates of nidus obliteration. Zabel du Bois et al (33) reported complete obliteration in $67 \%$ of patients at 3 years and $78 \%$ at 4 years for AVMs treated with NBCA (Braun, Melsungen, 


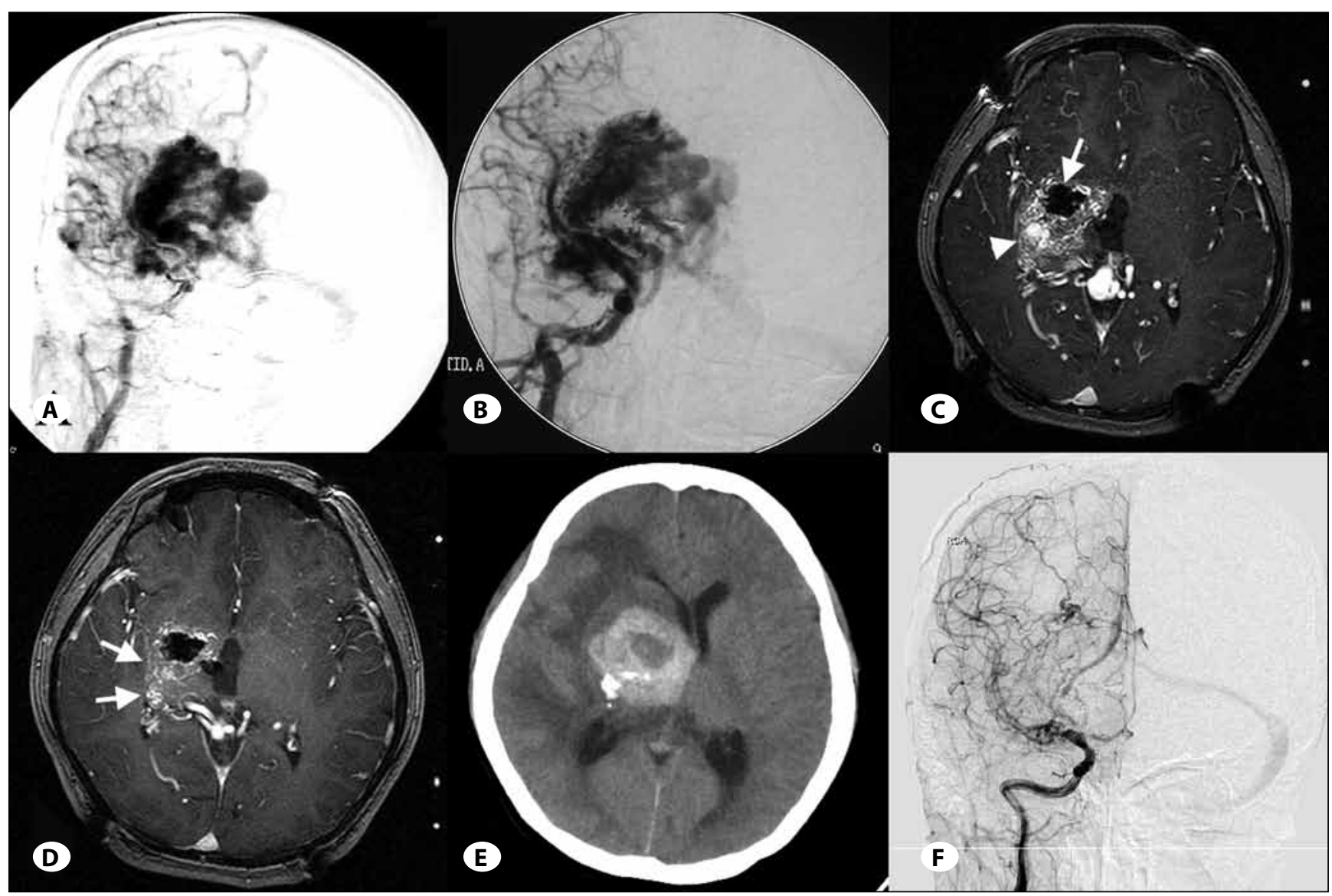

Figure 2: Hemorrhage after embolization combined with GKS. A) Angiogram (anterior-posterior projection) showing a basal ganglia AVM. B) DSA follow-up 4 months after the nidus was partially embolized by onyx. C) Residual nidus (white, arrow head) and onyx (black, arrow) were identified by 3D-TOF MRI before GKS. D) The volume of the residual nidus decreased significantly 23 months after GKS (arrows). The second GKS was performed for the residual nidus. E) The patient suddenly felt headache and CT showed a hemorrhage four years after the second GKS procedure. F) Angiogram showed a small residual nidus with very thin feeders unable to be embolized.

Germany) embolization and radiosurgery. Recently, Blackburn et al. (2) showed that staged endovascular embolization with NBCA followed by stereotactic radiosurgery provides an effective means to treat large AVMs $(3 \mathrm{~cm})$, obtaining a high rate of AVM obliteration after this combined treatment (81\%). In most studies dedicated to the combination therapy of embolization followed by radiosurgery for the treatment of brain AVMs, particles or glue were used as the embolization agent $(1,2,33)$. Only one study reported the use of Onyx as embolization agent for the combined treatment of embolization and radiosurgery and showed satisfactory results.

The annual hemorrhage rate in our series was lower than most reported annual hemorrhage risk of AVM which was about 1.3\%-4\% for unruptured AVMs and 6\%-7\% for ruptured $\operatorname{AVMs}(7,25)$. A recent meta-analysis study for natural history of AVM showed the overall annual hemorrhage rate was $3.0 \%$ with the rate of hemorrhage was $2.2 \%$ for unruptured AVMs and $4.5 \%$ for ruptured AVMs (10). In a group of 168 patients with untreated, unruptured AVMs, Brown et al. (3) reported an annual hemorrhage rate of 2.2\%. Dale Ding et al. (6) reported the post-radiosurgery annual hemorrhage rate for patients with unruptured AVM was 1.6\%. Xianli Lv et al. (19) reported an $2.4 \%$ annual hemorrhage rate for ruptured AVM after partial Onyx embolization. In a recent combined treatment study (28), the annual hemorrhage rate after GKS was $2 \%$ and did not differ from the non-embolized group, in which the annual hemorrhage rate was also $2 \%$. Hideyuki Kano also reported 120 patients underwent embolization followed by stereotactic radiosurgery and the overall annual hemorrhage rate was $2.7 \%$ (14).

In our series, the total annual hemorrhage rate was $1.66 \%$ for all the AVMs after combined treatment, $1.08 \%$ for unruptured and $2.26 \%$ for ruptured AVMs. For partially obliterated AVMs, the annual hemorrhage rate after combined treatment was $1.77 \%$ for all the AVMs without obliteration, $2.42 \%$ for ruptured AVMs and $1.16 \%$ for unruptured AVMs. From our data, combined treatment reduced the hemorrhage rate of AVMs when comparing with most reported data with radiosurgery or embolization alone or combination. 


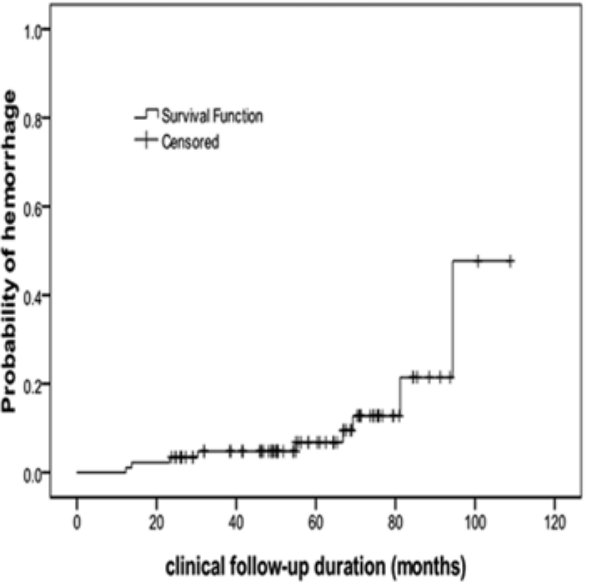

(A)

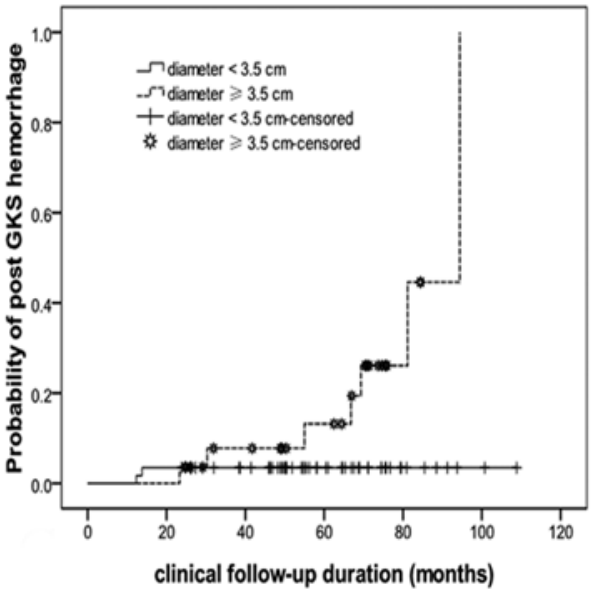

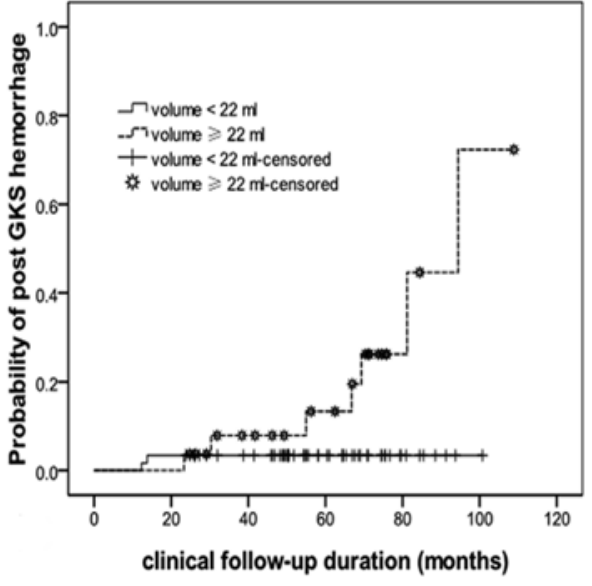

(B)

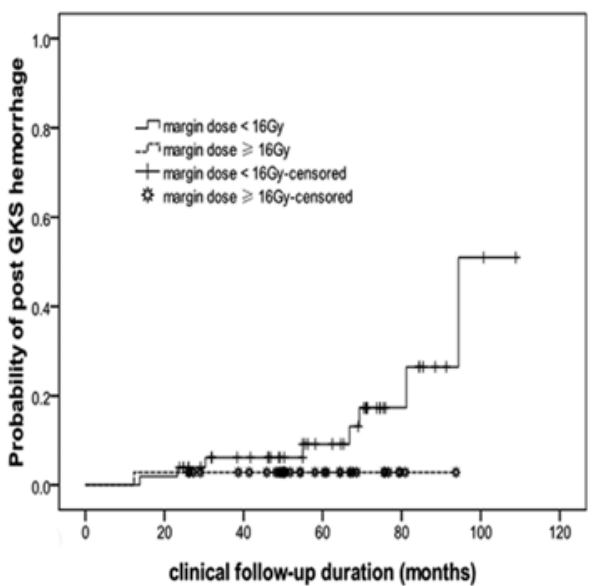

Figure 3: Factors predicting hemorrhage by Kaplan-Meier curves. A) Kaplan-Meier curves of hemorrhage after GKS for AVMs. B) Kaplan-Meier curves of hemorrhage after GKS for AVMs with volume of $22 \mathrm{ml}$ or larger versus less than $22 \mathrm{ml}$. Patients with AVMs with volume larger than $22 \mathrm{ml}$ had a significantly higher rate of hemorrhage after GKS $(p<0.05)$. C) Kaplan-Meier curves of hemorrhage after GKS for AVMs with prior GKS diameter $3.5 \mathrm{~cm}$ or larger versus less than $3.5 \mathrm{~cm}$. Patients with AVMs diameter prior GKS larger than $3.5 \mathrm{~cm}$ had a significantly higher rate of hemorrhage after GKS $(p<0.05)$. D) Kaplan-Meier curves of hemorrhage after GKS for AVMs with margin dose of 16 Gy or larger versus less than 16 Gy. Patients with AVMs with margin dose less than 16Gy had a significantly higher rate of hemorrhage after GKS $(p<0.05)$.

Even though our total obliteration rate is low, the clinical outcome is satisfactory. Lowered hemorrhage rate mainly attributed to Onyx embolization which could eliminate the hemorrhage risk factors of AVMs. Our multivariate analysis for multiple factors on hemorrhage showed that more Onyx volume, more residual nidus, deep location, more total volume, more feeding arteries, larger max diameter prior GKS, more decreased volume post embolization, less margin dose, less max dose, and higher Virginia Radio surgery AVM Scale were statistically significant independent positive predictors of hemorrhage. Except for margin dose and less max dose, all of these predictors were related to the diameter and volume of AVMs such as residual nidus and Virginia Radio surgery AVM Scale. So we further analyzed the volume and diameter of AVMs. Our data showed that AVMs volume prior embolization larger than $22 \mathrm{ml}$ had a significantly higher rate of hemorrhage after GKS $(p<0.05)$ and AVMs diameter prior GKS larger than $3.5 \mathrm{~cm}$ had a significantly higher rate of hemorrhage after GKS $(p<0.05)$. These predictors remained us that with Onyx embolization to decrease the residual nidus volume would decrease the hemorrhage rate of AVMs.

We know that GKS for AVM is a gradual progress which takes effect in two years. Embolization for AVM will leave partially embolized AVM more suitable and safer during GKS treatment. Our data also showed that patients with AVMs with margin dose less than 16Gy had a significantly higher rate of hemorrhage after GKS $(p<0.01)$. This provided us the 
idea that higher margin dose could decreased the volume of residual nidus and lowed the hemorrhage risk. However, a previous residual volume is important for the planning of GKS radiology dose. Lower residual volume facilitated the higher margin dose which might cause more adverse radiation effects (AREs) if prescribed with lager target volume. So by embolizing the AVM nidus to a suitable volume for GKS is of great importance for to decrease the hemorrhage and further obliteration.

However, the rate of total obliteration in our data is $28.2 \%$, which is lower than the reported study $(15,26,28)$. One important reason is the median volume $(14.1 \mathrm{ml})$ in our data is significantly larger than most reported studies $(15,26,28)$. So to decrease the nidus volume most suitable for GKS by Onyx embolization was difficult. However, we hold the idea that embolization is not mainly aiming to decreased the volume of the nidus, but serves to eliminate dangerous elements of the AVM such as intra-nidal or peri-nidal aneurysms and decrease the risk of hemorrhage. Embolization also could reduce the blood flow by obliterating arteriovenous fistulas within the AVM which decreased the dose attenuation of the GKS by blood flow $(21,32)$.

Additionally, we must keep in mind that AVM embolization carries its own set of complications, including microcatheter entrapment in Onyx, arterial perforation with the microcatheter, AVM hemorrhage due to premature draining vein occlusion, and stroke secondary to reflux of embolic agents into un-intended vessels. The combined morbidity and mortality rate from embolization complications is not trivial, exceeding $10 \%$ in some studies $(22,31)$. In our data, the post-embolization complications occurred in 13 patients (14.0\%), but most of the complications were transient and 10 patients' complication disappeared completely during the follow-up period. Embolization related hemorrhage didn't add up the disability or mortality for hemorrhage point could be embolized during the procedure and most hemorrhage is limited.

By using prior Onyx embolization, we aim to decrease the danger of hemorrhage for AVM and provide a safe duration for GKS to take effect. Even though combined treatment added up these two procedure's complications and appeared a low obliteration rate, we found a low hemorrhage rate from our data. But the low obliteration rate added hemorrhage risk for residual nidus of AVMs. For most partially obliterated AVMs reject further treatment, we need to give this combined treatment a long time follow-up to see its effect.

\section{Limitation of Our Study}

Comparing our results with radiosurgical series is difficult because the populations of patients are different from one series to another according to AVM size (or volume) and to other anatomic factors. Our study monocentric and retrospective, with a small patient population. The goal, however, was to analyze a population of patients treated in a homogeneous way, with a standardized technique of Onyx embolization and a homogeneous technique for radiosurgery.
Follow-up DSA investigations were not requested for all patients. Post GKS hemorrhage was only diagnosed by CT when a patient developed headache and asymptomatic hemorrhage was hardly seen by MRI follow-up.

\section{CONCLUSIONS}

In accordance with the literature, our experience suggests that Onyx embolization combined GKS treatment of AVMs was safe. Combined treatment decreased hemorrhage rate and the permanent clinical complication rate was low. This method could be proposed for the treatment of brain AVMs when a single-technique treatment is not feasible or as an alternative treatment to embolization followed by surgery. However, the total obliteration rate was low in our data and longer follow-up time and larger population are needed for evaluating further clinical effect of combined treatment.

\section{REFERENCES}

1. Andrade-Souza YM, Ramani M, Scora D, Tsao MN, terBrugge $\mathrm{K}$, Schwartz ML: Embolization before radiosurgery reduces the obliteration rate of arteriovenous malformations. Neurosurgery 60:443-451; discussion 451-442, 2007

2. Blackburn SL, Ashley WW Jr, Rich KM, Simpson JR, Drzymala RE, Ray WZ, Moran CJ, Cross DT 3rd, Chicoine MR, Dacey RG Jr, Derdeyn CP, Zipfel GJ: Combined endovascular embolization and stereotactic radiosurgery in the treatment of large arteriovenous malformations. Journal of Neurosurgery 114:1758-1767, 2011

3. Brown RD Jr, Wiebers DO, Forbes G, O'Fallon WM, Piepgras DG, Marsh WR, Maciunas RJ: The natural history of unruptured intracranial arteriovenous malformations. Journal of Neurosurgery 68:352-357, 1988

4. Dawson RC 3rd, Tarr RW, Hecht ST, Jungreis CA, Lunsford LD, Coffey R, Horton JA: Treatment of arteriovenous malformations of the brain with combined embolization and stereotactic radiosurgery: Results after 1 and 2 years. AJNR American Journal of Neuroradiology 11:857-864, 1990

5. DeMeritt JS, Pile-Spellman J, Mast H, Moohan N, Lu DC, Young WL, Hacein-Bey L, Mohr JP, Stein BM: Outcome analysis of preoperative embolization with $\mathrm{N}$-butyl cyanoacrylate in cerebral arteriovenous malformations. AJNR American Journal of Neuroradiology 16:1801-1807, 1995

6. Ding D, Yen CP, Xu Z, Starke RM, Sheehan JP: Radiosurgery for patients with unruptured intracranial arteriovenous malformations. Journal of Neurosurgery 118:958-966, 2013

7. Fleetwood IG, Steinberg GK: Arteriovenous malformations. Lancet 359:863-873, 2002

8. Fox AJ, Girvin JP, Vinuela F, Drake CG: Rolandic arteriovenous malformations: Improvement in limb function by IBC embolization. AJNR American Journal of Neuroradiology 6:575-582, 1985

9. Gobin YP, Laurent A, Merienne L, Schlienger M, Aymard A, Houdart E, Casasco A, Lefkopoulos D, George B, Merland J: Treatment of brain arteriovenous malformations by embolization and radiosurgery. Journal of Neurosurgery 85:19-28, 1996 
10. Gross BA, Du R: Natural history of cerebral arteriovenous malformations: A meta-analysis. Journal of Neurosurgery 118:437-443, 2013

11. Guo WY, Wikholm G, Karlsson B, Lindquist C, Svendsen $\mathrm{P}$, Ericson K: Combined embolization and gamma knife radiosurgery for cerebral arteriovenous malformations. Acta radiologica 34:600-606, 1993

12. Henkes $H$, Nahser HC, Berg-Dammer E, Weber W, Lange S, Kuhne D: Endovascular therapy of brain AVMs prior to radiosurgery. Neurological Research 20:479-492, 1998

13. Jafar JJ, Davis AJ, Berenstein A, Choi IS, Kupersmith MJ: The effect of embolization with $\mathrm{N}$-butyl cyanoacrylate prior to surgical resection of cerebral arteriovenous malformations. Journal of Neurosurgery 78:60-69, 1993

14. Kano $H$, Kondziolka D, Flickinger JC, Park KJ, lyer A, Yang HC, Liu X, Monaco EA 3rd, Niranjan A, Lunsford LD: Stereotactic radiosurgery for arteriovenous malformations after embolization: A case-control study. Journal of Neurosurgery 117:265-275, 2012

15. Kano H, Kondziolka D, Flickinger JC, Park KJ, lyer A, Yang HC, Liu X, Monaco EA 3rd, Niranjan A, Lunsford LD: Stereotactic radiosurgery after embolization for arteriovenous malformations. Progress in Neurological Surgery 27:89-96, 2013

16. Kusske JA, Kelly WA: Embolization and reduction of the "steal" syndrome in cerebral arteriovenous malformations. Journal of Neurosurgery 40:313-321, 1974

17. Luessenhop AJ, Mujica PH: Embolization of segments of the circle of Willis and adjacent branches for management of certain inoperable cerebral arteriovenous malformations. Journal of Neurosurgery 54:573-582, 1981

18. Luessenhop AJ, Spence WT: Artificial embolization of cerebral arteries. Report of use in a case of arteriovenous malformation. Journal of the American Medical Association 172: 1153-1155, 1960

19. Lv X, Wu Z, Li Y, Yang $X$, Jiang C: Hemorrhage risk after partial endovascular NBCA and ONYX embolization for brain arteriovenous malformation. Neurological Research 34: 552-556, 2012

20. Martin NA, Khanna R, Doberstein C, Bentson J: Therapeutic embolization of arteriovenous malformations: The case for and against. Clinical Neurosurgery 46:295-318, 2000

21. Miyachi S, Negoro M, Okamoto T, Kobayashi T, Kida Y, Tanaka T, Yoshida J: Embolisation of cerebral arteriovenous malformations to assure successful subsequent radiosurgery. Journal of Clinical Neuroscience 7 Suppl 1:82-85, 2000

22. Mounayer C, Hammami N, Piotin M, Spelle L, Benndorf G, Kessler I, Moret J: Nidal embolization of brain arteriovenous malformations using Onyx in 94 patients. AJNR American Journal of Neuroradiology 28:518-523, 2007
23. Ogilvy CS, Stieg PE, Awad I, Brown RD Jr, Kondziolka D, Rosenwasser R, Young WL, Hademenos G, Special Writing Group of the Stroke Council ASA: AHA Scientific Statement: Recommendations for the management of intracranial arteriovenous malformations: A statement for healthcare professionals from a special writing group of the Stroke Council, American Stroke Association. Stroke. Journal of Cerebral Circulation 32:1458-1471, 2001

24. Ogilvy CS, Stieg PE, Awad I, Brown RD Jr, Kondziolka D, Rosenwasser R, Young WL, Hademenos G, Stroke Council ASA: Recommendations for the management of intracranial arteriovenous malformations: A statement for healthcare professionals from a special writing group of the Stroke Council, American Stroke Association. Circulation 103: 2644-2657, 2001

25. Ondra SL, Troupp H, George ED, Schwab K: The natural history of symptomatic arteriovenous malformations of the brain: A 24-year follow-up assessment. Journal of Neurosurgery 73:387-391, 1990

26. Pierot L, Kadziolka K, Litre F, Rousseaux P:Combined treatment of brain AVMs with use of Onyx embolization followed by radiosurgery. AJNR American Journal of Neuroradiology 34:1395-1400, 2013

27. Pollock BE, Kondziolka D, Flickinger JC, Patel AK, Bissonette DJ, Lunsford LD: Magnetic resonance imaging: An accurate method to evaluate arteriovenous malformations after stereotactic radiosurgery. Journal of Neurosurgery 85: 1044-1049, 1996

28. Schwyzer L, Yen CP, Evans A, Zavoian S, Steiner L: Longterm results of gamma knife surgery for partially embolized arteriovenous malformations. Neurosurgery 71:1139-1147; discussion 1147-1138, 2012

29. Spetzler RF, Martin NA, Carter LP, Flom RA, Raudzens PA, Wilkinson E: Surgical management of large AVM's by staged embolization and operative excision. Journal of Neurosurgery 67:17-28, 1987

30. Starke RM, Yen CP, Ding D, Sheehan JP: A practical grading scale for predicting outcome after radiosurgery for arteriovenous malformations: Analysis of 1012 treated patients. Journal of Neurosurgery 119:981-987, 2013

31. van Rooij WJ, Sluzewski M, Beute GN: Brain AVM embolization with Onyx. AJNR American Journal of Neuroradiology 28: 172-177; discussion 178, 2007

32. Yuki I, Kim RH, Duckwiler G, Jahan R, Tateshima S, Gonzalez N, Gorgulho A, Diaz JL, De Salles AA, Vinuela F:Treatment of brain arteriovenous malformations with high-flow arteriovenous fistulas: Risk and complications associated with endovascular embolization in multimodality treatment. Clinical article. Journal of Neurosurgery 113:715-722, 2010

33. Zabel-du Bois A, Milker-Zabel S, Huber P, Schlegel W, Debus $\mathrm{J}$ : Risk of hemorrhage and obliteration rates of LINAC-based radiosurgery for cerebral arteriovenous malformations treated after prior partial embolization. International Journal of Radiation Oncology, Biology, Physics 68:999-1003, 2007 